\title{
ESTIMATES OF GENETIC PARAMETERS FOR SELECTION OF COLORED COTTON FIBER ${ }^{1}$
}

\author{
ROMMEL RAPHAEL SANTOS DE ALBUQUERQUE ${ }^{2 *}$, JOSÉ JAIME VASCONCELOS CAVALCANTI ${ }^{3}$, \\ FRANCISCO JOSÉ CORREIA FARIAS ${ }^{3}$, DAMIÃO RANIERE QUEIROZ ${ }^{4}$, LUIZ PAULO DE CARVALHO ${ }^{3}$
}

\begin{abstract}
Naturally-colored cotton fiber has received attention from breeding programs in the semiarid region of northeastern Brazil due to an increased interest in its fibers. Therefore, this study aimed to select genotypes of colored cotton fiber for agronomic and technological fiber characteristics for the Brazilian semiarid conditions. The experiment was carried out in two environments (Patos-PB and Apodi-RN) in Brazil during the 2016 growing season. The experimental design was in randomized blocks with four replications. Treatments consisted of eleven colored fiber genotypes and three controls (BRS Topázio, BRS Rubi, and BRS Verde). The following traits were assessed: seed cotton yield (SCY, $\mathrm{kg} \mathrm{ha}^{-1}$ ), lint percentage (LP, \%), lint length (LEN, mm), lint strength (STR, $\mathrm{gf} \mathrm{tex}^{-1}$ ), and lint micronaire (MIC, $\mu \mathrm{g}$ in ${ }^{-1}$ ). The data were submitted to individual and joint variance analyses, and means were grouped by the Scott and Knott (1974) test at 0.05 probability. Genotypes showed variability in all traits, which allows genetic gains in subsequent cycles of selection. The genotypes BRS Topázio, CNPA 2002 10245, and CNPA 200210327 presented the best estimates for the assessed traits, thus they can be selected for future studies in cotton breeding programs in the semiarid region.
\end{abstract}

Keywords: Plant breeding. Genetic gains. Gossypium hirsutum L.

\section{ESTIMATIVAS DE PARÂMETROS GENÉTICOS PARA SELEÇÃO DE ALGODOEIRO DE FIBRA COLORIDA}

RESUMO - O algodoeiro de fibra natural colorida tem recebido atenção dos programas de melhoramento na região semiárida do Nordeste brasileiro devido ao aumento no interesse por este tipo de fibra. Com isso, o objetivo deste trabalho foi selecionar genótipos de algodoeiro de fibra colorida quanto às características agronômicas e tecnológicas da fibra para as condições da região semiárida brasileira. $\mathrm{O}$ experimento foi realizado em dois ambientes (Patos-PB e Apodi-RN), na safra de 2016. O delineamento foi blocos ao acaso com quatro repetições. Foram utilizados 11 genótipos de fibra colorida e três testemunhas (BRS Topázio, BRS Rubi e BRS Verde), constituindo 14 tratamentos. As características avaliadas foram: Produtividade de algodão em caroço (PROD, kg.ha ${ }^{-1}$ ), Porcentagem de fibra (PF, \%), Comprimento de fibra (COMP, mm), Resistência $\left(\right.$ RES, gf.tex $\left.{ }^{-1}\right)$ e Finura (FIN, $\mu$ g.in $\left.{ }^{-1}\right)$. Os dados foram submetidos à análise de variância individual e conjunta e as médias foram agrupadas pelo teste de Scott e Knott (1974) a 0.05 de probabilidade. Os genótipos apresentaram variabilidade para as características estudadas com possibilidade de ganhos genéticos em ciclos posteriores de seleção. BRS Topázio, CNPA 200210245 e CNPA 200210327 apresentaram as melhores estimativas para as características avaliadas, sendo selecionados para futuros trabalhos de melhoramento do algodoeiro para o semiárido.

Palavras-chave: Melhoramento vegetal. Ganhos genéticos. Gossypium hirsutum L.

\footnotetext{
${ }^{*}$ Corresponding author

${ }^{1}$ Received for publication in $01 / 04 / 2019$; accepted in $11 / 28 / 2019$.

Paper extracted from the Master's thesis of the first author.

${ }^{2}$ Department of Agricultural Sciences, Universidade Estadual da Paraíba, Campina Grande, PB, Brazil; raphaelw3@gmail.com - ORCID: 0000-0003-1035-0509.

${ }^{3}$ National Cotton Research Center, Empresa Brasileira de Pesquisa Agropecuária, Campina Grande, PB, Brazil; jaime.cavalcanti@embrapa.br _ ORCID: 0000-0003-4510-7648, francisco.farias@embrapa.br - ORCID: 0000-0002-7213-0694, luiz.carvalho@embrapa.br - ORCID: 0000-0002-8601-5857.

${ }^{4}$ Agronomy department, Universidade Federal Rural de Pernambuco, Recife, PE, Brazil; damiao_queiroz@yahoo.com.br - ORCID: 00000003-4140-7424.
} 


\section{INTRODUCTION}

Herbaceous cotton (Gossypium hirsutum L.) is among the three most important crops in Brazilian agribusiness. Brazil stands out as the world's fourthlargest producer and third largest exporter of cotton (FREIRE et al., 2015; ABRAPA, 2017; FAO, 2018; USDA-FAS, 2018). The Brazilian Midwest is the largest producer, followed by the Northeast region. For both regions in the 2017/2018 growing season, production estimates were over 200 thousand tons (CONAB, 2018).

In Brazil, fiber production has always been based on the cultivation of white cotton fiber, with a large number of cultivars with great productive potential and excellent fiber quality. Cotton breeding programs in the twentieth century were directed at white cotton fiber, while those of colored fiber have been used only by hand or as an ornamental plant (CARVALHO et al., 2015a).

The interest in colored cotton fiber cultivation in the Northeast region by family farming has increased in the current century, mainly because farmers sell colored fibers at a better price when compared to white fiber. To meet this demand, Embrapa Cotton has been carrying out breeding programs since the mid-1990s to select colored fiber cultivars with good yield associated with fiber traits within the standards of the textile industry (CARVALHO; ANDRADE; SILVA FILHO, 2011; CARVALHO, 2016). However, climate irregularities in the semiarid of the Northeast region led to the need to develop and select new cotton cultivars that, in addition to being productive and having superior fiber quality, are adapted or tolerant to water stress (CARVALHO et al., 2015a; DEEBA et al., 2012; DHIVYA et al., 2014).

Therefore, colored cotton fiber cultivars have become an important alternative for producers, as they have a high economic value and profitability, adding value to northeastern agriculture and changing the perspective of family farming, which needs a new dynamic to become competitive in the current market.

Several studies have been developed to select colored cotton fiber genotypes for the semiarid region. Carvalho et al. (2005) observed the effect of mass selection on colored fiber genotypes to obtain genetic gains for the percentage of lint, while Carvalho et al. (2015a) verified the presence of interaction genotype $\mathrm{x}$ environment $(\mathrm{GxE})$ and determined the adaptability and phenotypic stability of eleven brown-colored cotton fiber genotypes under irrigated and rainfed conditions.

Thus, this study aimed to select superior genotypes of colored cotton fiber for agronomic and technological traits of fibers with wide adaptability to the Brazilian semiarid conditions.

\section{MATERIAL AND METHODS}

\section{Experimental driving}

The experiment was carried out under field conditions in two locations representative of the northeastern semi-arid conditions. The first area was located at the experimental station of EMPARN (Agricultural Research Corporation of Rio Grande do Norte) in the municipality of Apodi-RN (Brazil), while the second area was located at the experimental station of EMBRAPA (Brazilian Agricultural Research Corporation) in the municipality of Patos-PB (Brazil).

Planting was carried out in February 2016 in Apodi-RN and September 2016 in Patos-PB, using a randomized block design with four replications and 14 treatments (11 genotypes and three controls), with the experimental plot consisting of two rows of $5 \mathrm{~m}$ long and an interrow spacing of $0.90 \mathrm{~m}$. The experiment was carried out following management recommendations for the crop, and fertilization was carried out based on soil analysis at each location.

During the experiment, two irrigations were carried out per week for two hours each, thus totaling $40 \mathrm{~mm}$ of water per week ( $20 \mathrm{~mm}$ per day). In the week when precipitation was higher than $30 \mathrm{~mm}$, the irrigation system was suspended the following day, with no need for irrigation that week. The irrigation system was activated only once a week when there was more than $10 \mathrm{~mm}$ of precipitation, providing only $20 \mathrm{~mm}$ of water per week for the plants.

Cotton harvest was performed manually in July 2016 in Apodi-RN and January 2017 in PatosPB. The following traits were assessed: seed cotton yield (SCY, $\mathrm{kg} \mathrm{ha}^{-1}$ ), percentage of lint (LP, \%), length (LEN, mm), strength (STR, gf tex ${ }^{-1}$ ), and micronaire (MIC, $\mu \mathrm{g}$ in $^{-1}$ ). Fiber characteristics were estimated using a high-volume instrument (HVI).

The cotton genotypes came from the active germplasm bank of Embrapa, and were previously chosen for superior fiber quality and tolerance to water stress (Table 1). 
Table 1. Genotypes of colored cotton fiber used for the selection study under water supplementation conditions, Apodi-RN and Patos-PB (Brazil).

\begin{tabular}{lcl}
\hline Treatment & Genotype & Fiber color \\
\hline 1 & BRS Topázio* & Light brown \\
2 & BRS Rubi* & Dark brown \\
3 & BRS Verde* & Green \\
4 & CNPA 2006 3667 & Light brown \\
5 & CNPA 2006 3269 & Light brown \\
6 & CNPA 2006 3334 & Light brown \\
7 & CNPA 2002 10576 & Light brown \\
8 & CNPA 2002 10245 & Light brown \\
9 & CNPA 2002 10327 & Light brown \\
10 & CNPA 98 1034 & Light brown \\
11 & CNPA 2001 5823 & Light brown \\
12 & CNPA 2002 10575 & Light brown \\
13 & CNPA 2002 10398 & Light brown \\
14 & CNPA 2002 10087 & Light brown \\
$*$ Controls. & &
\end{tabular}

\section{Statistical analysis}

Individual analyses of variance were carried out for each environment, considering the effects of treatment and environment as fixed. Subsequently, an analysis of joint variance was performed. The relationship between the highest and lowest mean squared residuals was lower than seven, showing that residual variances were homogeneous (GOMES, 2000). The statistical model used in the joint analysis was as follows $\mathrm{Y}_{\mathrm{ijk}}=\mu+\mathrm{b}_{\mathrm{a}_{\mathrm{jk}}}+\mathrm{g}_{\mathrm{i}}+\mathrm{a}_{\mathrm{j}}+\mathrm{ga}_{\mathrm{ij}}+\mathrm{e}_{\mathrm{ijk}}$, where $\mathrm{Y}_{\mathrm{ijk}}$ is the phenotypic value of genotype $\mathrm{i}$ in environment $j, \mu$ is the overall mean, $(b / a)_{j k}$ is the effect of blocks $(\mathrm{k}=1,2, \ldots, \mathrm{r})$ within environments $(j=1,2, \ldots, q), g_{i}$ is the effect of genotypes $(i=1,2$, $\ldots, p), a_{j}$ is the effect of environments $(j=1,2, \ldots$, q), $\mathrm{ga}_{\mathrm{ij}}$ is the effect of genotype $\mathrm{x}$ environment interaction, and $\mathrm{e}_{\mathrm{ijk}}$ is the random error (CRUZ; REGAZZI; CARNEIRO, 2012).

The genetic parameters from the joint analysis were estimated by:

(2) CVe (\%): coefficient of environmental variation: $\mathrm{CV}_{\mathrm{e}}=100\left(\frac{\sqrt{\mathrm{MSR}}}{\overline{\mathrm{Y}}}\right)$ where MSR is the mean squared residuals and $\bar{Y}$ is the overall mean.

(3) QCg: genotypic quadratic component: $\mathrm{QCg}=\frac{\mathrm{GMS}-\mathrm{MSR}}{\mathrm{ar}}$, where GMS is the genotype average square, $a$ is the number of environments, and $r$ is the number of replications.

(4) QCgxe: GxE interaction quadratic QCgxe $=\frac{\text { GEMS }- \text { MSR }}{r}$, where

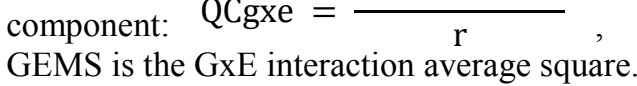

(5) CGD (\%): coefficient of genotypic determination: $\mathrm{CGD}=\frac{\mathrm{CQg}}{\mathrm{QMG} / \mathrm{r}}$, where $\mathrm{QCg}$ : genotypic quadratic component.

(6) $\mathrm{CVg}(\%)$ : coefficient of genetic variation: $\operatorname{CVg}=\left(\frac{\sqrt{\mathrm{QCg}}}{\mu}\right) 100$, where $\mu$ is the mean of the variable.

(7) $\mathrm{Vg} / \mathrm{CVe}$ : the ratio between the coefficient of genetic variation and the coefficient of environmental variation:

$$
\text { Ratio }=\mathrm{CVg} / \mathrm{CVe} \text {. }
$$

Treatment means were grouped by the Scott and Knott (1974) test at 0.05 probability. Data analyses were performed using the software GENES version 1990.2018.49 (CRUZ, 2013).

\section{RESULTS AND DISCUSSIONS}

The summary of joint variance analysis (Table 2) showed significant differences $(p<0.01)$ for all traits. As such, the genotypes have genetic variability and hence favorable responses to selection. Regarding the environmental effect, the genotypes showed significant differences $(p<0.01)$ only for traits LP and LEN. Yet for GxE interaction, significant differences were observed only for SCY $(p<0.01)$ and MIC $(p<0.05)$, that is, the genotypes have different behaviors in each environment for these traits. Similar results were found by Carvalho et al. (2015a), who observed different behaviors of colored cotton fiber genotypes as a function of the environment, indicating the need for further studies of adaptability and phenotypic stability. 
Table 2. Joint variance analysis and estimation of genetic parameters of seed cotton yield (SCY, $\mathrm{kg} \mathrm{ha}^{-1}$ ), lint percentage (LP, \%), lint length (LEN, mm), lint strength (STR, $\mathrm{gf} \mathrm{tex}^{-1}$ ), and lint micronaire (MIC, $\mu \mathrm{g} \mathrm{in}^{-1}$ ) for 14 colored cotton genotypes, Apodi-RN and Patos-PB (Brazil).

\begin{tabular}{|c|c|c|c|c|c|c|}
\hline \multirow{2}{*}{$\begin{array}{l}\text { Variation } \\
\text { source }\end{array}$} & \multirow{2}{*}{$\mathrm{DF}$} & \multicolumn{5}{|c|}{ 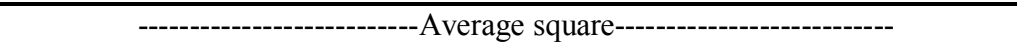 } \\
\hline & & SCY & LP & LEN & STR & MIC \\
\hline Genotype & 13 & $948028.57 * *$ & $74.52 * *$ & $42.51 * *$ & $77.03 * *$ & $1.72 * *$ \\
\hline Environment & 1 & 817213.14 & $73.45 * *$ & $43.87 * *$ & 15.08 & 0.35 \\
\hline GxE & 13 & $1001337.15^{* *}$ & 2.97 & 2.24 & 3.42 & $0.18^{*}$ \\
\hline Residual & 78 & 135223.31 & 1.78 & 2.34 & 3.47 & 0.08 \\
\hline Mean & & 3030.61 & 35.91 & 27.96 & 30.16 & 4.39 \\
\hline $\mathrm{CVe}(\%)$ & & 12.13 & 3.71 & 5.47 & 6.17 & 6.71 \\
\hline QCg & & 101600.65 & 9.09 & 5.02 & 9.19 & 0.20 \\
\hline QCgxe & & 216528.46 & 0.29 & -0.02 & -0.01 & 0.02 \\
\hline RV & & 135223.31 & 1.78 & 2.34 & 3.47 & 0.08 \\
\hline CGD (\%) & & 85.73 & 97.60 & 94.48 & 95.49 & 94.94 \\
\hline $\operatorname{CVg}(\%)$ & & 10.51 & 8.39 & 8.01 & 10.05 & 10.29 \\
\hline $\mathrm{CVg} / \mathrm{CVe}$ & & 0.86 & 2.25 & 1.46 & 1.62 & 1.53 \\
\hline
\end{tabular}

DF: degrees of freedom; CVe: coefficient of environmental variation; $\mathrm{QCg}$ : genotypic quadratic component; QCgxe: GxE interaction quadratic component; RV: residual variance; CGD: coefficient of genotypic determination (mean); $\mathrm{CVg}$ : Coefficient of genetic variation; $\mathrm{CVg} / \mathrm{CVe}$ : $\mathrm{CVg} / \mathrm{CVe}$ ratio; * and **: significant at 0.05 and 0.01 probability by the F-test, respectively.

All evaluated genotypes showed trait averages (Table 2) in accordance with mean standards for colored herbaceous cotton medium fiber, except for LP (35.91\%). This parameter has a recommendation of above 40\% (VIDAL NETO; FREIRE, 2013).

CVe (\%) presented changes (Table 2). The highest CVe was found for SCY (12.13\%) and the lowest for LP (3.71\%), indicating a good experimental precision. Similar results for experiments with cotton cultivation in semiarid regions were found by Cordão Sobrinho et al. (2015), Queiroz et al. (2017), and Vasconcelos et al. (2018).

Regarding genetic parameters from joint variance analysis (Table 2), coefficient of genotypic determination (CGD) ranged from $85.73 \%$ (SCY) to $97.60 \%$ (LP), showing a significant presence of genotypic variability regarding total phenotypic variability for all traits. This indicates the possibility of significant gains in the selection process. According to Bonifácio, Mundim, and Sousa (2015), CGD above $70 \%$ can be considered high and desirable; however, it varies according to species and assessed trait. Cruz, Regazzi, and Carneiro (2012) reported that heritability coefficient estimates, which corresponds to CGD for fixed models, are important for choosing an effective selection strategy.

Our CGD estimates were higher than those found in other studies (KHAN et al., 2010; RESENDE et al., 2014; and KOTHARI el al., 2016). These authors obtained discrepant estimates, ranging from $77 \%$ to $87 \%$ for LEN and from $0 \%$ to $81.10 \%$ for MIC. Such differences are due to genotype and environmental conditions.

According to Carvalho et al. (2016), a coefficient of genetic variation $(\mathrm{CVg})$ (Table 2) can be interpreted as the magnitude of the genetic variation available for selection, among which the highest are mostly desired. The highest $\mathrm{CVg}$ estimates were found for traits SCY (10.51\%), MIC
(10.29\%), and STR (10.05\%), while LEN (8.01\%) presented the lowest value. Resende et al. (2014) obtained a higher CVg for LP (14.010\%) when studying cotton.

The $\mathrm{CVg} / \mathrm{CVe}$ ratio quantifies the proportion of genetic in relation to environmental variance (BORÉM; MIRANDA; FRITSCHE-NETO, 2013) and expresses the degree of selection difficulty. In our study, $\mathrm{CVg} / \mathrm{CVe}$ estimates were higher than the unit in all traits (Table 2), except for SCY (0.86), i.e., offering advantages for selection. According to Vencovsky and Barriga (1992), values similar to or higher than one are favorable to selection.

Table 3 shows the grouping of means for the studied parameters from the Scott and Knott (1974) test at 0.05 probability (mean of both studied environments). Several groups were formed for all the traits, thus confirming the genetic variability of these parameters among genotypes.

Two groups were formed for SCY (Table 3), standing out the genotypes CNPA 200210087 (3618.83 $\left.\mathrm{kg} \mathrm{ha}^{-1}\right)$ and CNPA 200210398 (3485.42 $\left.\mathrm{kg} \mathrm{ha}^{-1}\right)$, which exceeded the controls. This finding corroborates the results found by Carvalho et al. (2015b). Zonta et al. (2015a) reported water deficit influence on yield of cotton cultivars under varied irrigation depths, with values lower than those verified in our study.

Five groups were formed for LP, standing out the control BRS Topázio (41.96\%), followed by the genotypes: CNPA 2002 10327, CNPA 2002 10398, CNPA 2001 5823, and CNPA 98 1034. The control BRS Verde was classified in the last group, with the lowest LP. A similar result was found by Carvalho et al. (2015b), who reported an overall mean of $36.02 \%$ for LP. Cordão Sobrinho et al. (2015) used five water regime conditions and observed no influence of water depths on LP, finding higher values for LP 
for the cultivars BRS Aroeira (44.25\%) and BRS Araripe (42.77\%). Zonta et al. (2015a) also observed results similar to ours using a $360 \mathrm{~mm}$ water depth for cotton irrigation.

Three groups were formed for LEN, standing out the genotypes CNPA 2002 10575, CNPA 2002 10576, CNPA 2002 10245, and CNPA 2002 10327, which exceeded the controls. Carvalho et al. (2015b) used the irrigation regime recommended for cotton cultivation and observed similar means for length compared to our results. Zonta et al. (2015a) found similar means for length using different irrigation depths, while Cordão Sobrinho et al. (2015) reported that the amount of water made available to cotton caused a direct effect on length.

Table 3. Grouping of means for seed cotton yield (SCY, $\mathrm{kg} \mathrm{ha}^{-1}$ ), lint percentage (LP, \%), lint length (LEN, mm), lint strength (STR, gf tex ${ }^{-1}$ ), and lint micronaire (MIC, $\mu \mathrm{g}$ in $^{-1}$ ) for 14 colored cotton genotypes, Apodi-RN and Patos-PB (Brazil).

\begin{tabular}{lccccc}
\hline Genotype & SCY $\left(\mathrm{kg} \mathrm{ha}^{-1}\right)$ & LP $(\%)$ & LEN $(\mathrm{mm})$ & STR $\left(\mathrm{gf} \mathrm{tex}^{-1}\right)$ & MIC $\left(\mu \mathrm{g} \mathrm{in}^{-1}\right)$ \\
\hline BRS Topázio* & $3442.26 \mathrm{a}$ & $41.96 \mathrm{a}$ & $29.21 \mathrm{a}$ & $29.75 \mathrm{~b}$ & $4.77 \mathrm{a}$ \\
BRS Rubi* $_{\text {BRS Verde* }}^{2407.73 \mathrm{~b}}$ & $34.20 \mathrm{~d}$ & $21.17 \mathrm{c}$ & $22.91 \mathrm{c}$ & $4.26 \mathrm{~b}$ \\
CNPA 2006 3667 & $2861.07 \mathrm{~b}$ & $27.67 \mathrm{e}$ & $25.87 \mathrm{~b}$ & $23.72 \mathrm{c}$ & $2.95 \mathrm{c}$ \\
CNPA 2006 3269 & $3221.80 \mathrm{a}$ & $34.73 \mathrm{~d}$ & $27.42 \mathrm{~b}$ & $32.41 \mathrm{a}$ & $4.71 \mathrm{a}$ \\
CNPA 2006 3334 & $2695.89 \mathrm{~b}$ & $35.95 \mathrm{c}$ & $27.16 \mathrm{~b}$ & $30.47 \mathrm{~b}$ & $4.51 \mathrm{a}$ \\
CNPA 2002 10576 & $2716.88 \mathrm{~b}$ & $35.03 \mathrm{~d}$ & $27.95 \mathrm{~b}$ & $32.27 \mathrm{a}$ & $4.41 \mathrm{~b}$ \\
CNPA 2002 10245 & $3144.62 \mathrm{~b}$ & $35.42 \mathrm{c}$ & $29.83 \mathrm{a}$ & $32.60 \mathrm{a}$ & $4.67 \mathrm{a}$ \\
CNPA 2002 10327 & $3274.49 \mathrm{a}$ & $36.25 \mathrm{c}$ & $29.71 \mathrm{a}$ & $30.71 \mathrm{~b}$ & $4.12 \mathrm{~b}$ \\
CNPA 98 1034 & $2919.67 \mathrm{~b}$ & $36.55 \mathrm{~b}$ & $29.31 \mathrm{a}$ & $32.15 \mathrm{a}$ & $4.42 \mathrm{~b}$ \\
CNPA 2001 5823 & $2858.70 \mathrm{~b}$ & $37.45 \mathrm{~b}$ & $27.25 \mathrm{~b}$ & $29.63 \mathrm{~b}$ & $4.61 \mathrm{a}$ \\
CNPA 2002 10575 & $2868.79 \mathrm{~b}$ & $35.73 \mathrm{c}$ & $30.12 \mathrm{a}$ & $31.05 \mathrm{~b}$ & $4.66 \mathrm{a}$ \\
CNPA 2002 10398 & $3485.42 \mathrm{a}$ & $37.46 \mathrm{~b}$ & $28.46 \mathrm{a}$ & $33.23 \mathrm{a}$ & $4.41 \mathrm{~b}$ \\
CNPA 2002 10087 & $3618.83 \mathrm{a}$ & $36.01 \mathrm{c}$ & $28.87 \mathrm{a}$ & $30.96 \mathrm{~b}$ & $4.78 \mathrm{a}$ \\
\hline
\end{tabular}

Means followed by the same letter belong to the same group by the Scott and Knott test at 0.05 probability; *: controls.

The group formed by genotypes CNPA 2002 10575, CNPA 2002 10576, CNPA 20063667, CNPA 2006 3334, and CNPA 200210327 stood out for STR, surpassing all the other genotypes and controls. Similar results were found by Carvalho et al. (2015b), Zonta et al. (2015b), and Cordão Sobrinho et al. (2015), using irrigation depths similar to the ones we assessed.

Three groups of genotypes were formed for MIC. The lowest MIC was expressed by the control BRS Verde $\left(2.95 \mu \mathrm{g} \mathrm{in}^{-1}\right)$, followed by the genotype CNPA $200210245\left(4.12 \mu \mathrm{g} \mathrm{in}{ }^{-1}\right)$. These results exceeded those found by Cordão Sobrinho et al. (2015) and Zonta et al. (2015b), while Carvalho et al. (2015b) observed micronaire estimates ranging from 2.70 to $4.25 \mu \mathrm{g} \mathrm{in}^{-1}$ when using the irrigation regime recommended for cotton.

\section{CONCLUSION}

Significant genetic variability was found among the studied colored cotton genotypes, allowing significant gains in selection for the semiarid conditions of northeastern Brazil.

The best performing genotypes were BRS Topázio, CNPA 2002 10245, and CNPA 2002 10327 , as they achieved high cotton yields associated with superior fiber characteristics, with satisfactory tolerance to water stress. Thus, these genotypes can be used in breeding programs for colored cotton fiber quality in the semi-arid region of northeastern Brazil.

\section{ACKNOWLEDGMENTS}

The authors would like to thank the Brazilian Agricultural Research Corporation, unit of Campina Grande-PB (Embrapa Cotton) and the State University of Paraíba (UEPB) for their institutional and financial support, and the Coordination for the Improvement of Higher Education Personnel (CAPES) for granting a master's degree scholarship to the first author.

\section{REFERENCES}

ASSOCIAÇÃO BRASILEIRA DE PRODUTORES DE ALGODÃO - ABRAPA. Dados - Algodão no mundo. Available at: <http://www.abrapa.com.br/ Paginas/dados/algodao-no-mundo.aspx $>$. Accessed on: Sep 14, 2017.

BONIFÁCIO, D. O. C.; MUNDIM, F. M. SOUSA, L. B. Variabilidade genética e coeficiente de determinação em genótipos de algodoeiro quanto a qualidade da fibra. Revista Verde, 10: 66-71, 2015. 
BORÉM, A.; MIRANDA, G. V.; FRITSCHENETO, R. Melhoramento de plantas. 7. ed. Viçosa, MG: UFV, 2017. 543 p.

CARVALHO, L. P.; ANDRADE, F. P.; SILVA FILHO, J. L. Cultivares de algodão colorido do Brasil. Revista Brasileira de Oleaginosas e Fibrosas, 15: 37-44, 2011.

CARVALHO, L. P. et al. Agronomic and technical fibers traits in elite genotypes of cotton herbaceous. African Journal of Agricultural Research, 10: 4882-4887, 2015b.

CARVALHO, L. P. et al. Estabilidade e adaptabilidade de genótipos de algodão de fibra colorida quanto aos caracteres de fibra. Ciência Rural, 45: 598-605, 2015a

CARVALHO, L. P. et al. Seleção massal e porcentagem de fibra em cultivar de algodoeiro herbáceo. Pesquisa Agropecuária Brasileira, 40: 895-898, 2005.

CARVALHO, L. P. et al. Uso da metodologia REML/BLUP para seleção de genótipos de algodoeiro com maior adaptabilidade e estabilidade produtiva. Bragantia, 75: 314-321, 2016.

CARVALHO, L. P. Novas linhagens de algodoeiro herbáceo com coloração na fibra. 1. ed. Campina Grande, PB: Embrapa Algodão, 2016. 17 p. (Documentos, 262).

\section{COMPANHIA}

NACIONAL

$\mathrm{DE}$

ABASTECIMENTO - CONAB. Acompanhamento da Safra Brasileira de Grãos 2017/2018. Sétimo levantamento, Abril de 2018. Available at: $<$ https:// www.conab.gov.br/index.php/info-agro/safras $>$.

Accessed on: May 25, 2018.

CORDÃO SOBRINHO, F. P. et al. Fiber quality of upland cotton under different irrigation depths. Revista Brasileira de Engenharia Agrícola e Ambiental, 19: 1057-1063, 2015.

CRUZ, C. D.; REGAZZI, A. J. CARNEIRO, P. C. $\mathrm{S}$. Modelos biométricos aplicados ao melhoramento genético. 4. ed. Viçosa, MG: UFV, $2012.514 \mathrm{p}$

CRUZ, C. D. GENES: a software package for analysis in experimental statistic and quantitative genetics. Acta Scientiarum. Agronomy, 35: 271276, 2013.

DEEBA, F. et al. Physiological and proteomic responses of cotton (Gossypium herbaceum L.) to drought stress. Plant Physiology and Biochemistry, 53: 6-18, 2012.
DHIVYA, R. et al. Variability, heritability and genetic advance in upland cotton (Gossypium hirsutum L.). African Journal of Plant Science, 8: $1-5,2014$

FOOD AND AGRICULTURE OGANIZATION OF THE UNITED NATIONS - FAO. Statistics divison. Available at: <http://www.fao.org/faostat/en/\#data/ QC/visualize>. Accessed on: May 25, 2018.

FREIRE, E. C. et al. Melhoramento do algodoeiro: cultivares convencionais e transgênicas para o cerrado. In: FREIRE, E. C. (Ed.) Algodão no cerrado do Brasil. Brasília: Associação Brasileira dos Produtores de Algodão, 2015. v. 1, cap. 6, p. 151 -201 .

KHAN, N. U. et al. genetic variation and heritability for cotton seed, fiber and oiltraits in Gossypium hirsutum L. Pakistan Journal of Botany, 42: 615625. 2010

KOTHARI, N. et al. Combining Ability and performance of cotton germplasm with diverse seed oil content. Crop Science. 56: 19-29, 2016.

GOMES, F. P. Curso de estatística experimental. 14. ed. Piracicaba, SP: Degaspari, 2000. 477 p.

QUEIROZ, D. R. et al. Diallel analyses for technological traits in upland cotton. Genetics and Molecular Research, 16: 1-8, 2017.

RESENDE, M. A. V. et al. Divergência genética e índice de seleção via BLUP em acessos de algodoeiro para características tecnológicas da fibra. Pesquisa Agropecuária Tropical, 44: 334-340, 2014.

SCOTT, A. J.; KNOTT, M. A cluster analysis method for grouping means in the analysis of variance. Biometrics, 30: 507-512, 1974.

\section{UNITED STATE DEPARTMENT OF} AGRICULTURE - FOREIGN AGRICULTURAL SERVICE - USDA-FAS. Crop Explorer. Available at: <https://ipad.fas.usda.gov/cropexplorer/cropview/ commodityView.aspx?cropid $=2631000>$. Accessed on: Sep 17, 2018.

VASCONCELOS, V. A. A. et al. Diallel analysis in cotton (Gossypium hirsutum L.) for water stress tolerance. Crop Breeding and Applied Biotechnology, 18: 24-30, 2018.

VENCOVSKY, R.; BARRIGA， P. Genética biométrica no fitomelhoramento. 1. ed. Ribeirão Preto, SP: Sociedade Brasileira de Genética, 1992. $492 \mathrm{p}$. 
VIDAL NETO, F. C; FREIRE, E. C. Melhoramento genético do algodão. In: VIDAL NETO, F. C; CAVALCANTI, J. J. V. (Eds.). Melhoramento genético de plantas no Nordeste. Brasília: Embrapa, 2013. cap. 3, p. 49-83.

ZONTA, J. H. et al. Efeito da irrigação no rendimento e qualidade de fibras em cultivares de algodoeiro herbáceo. Revista Caatinga, 28: 43-52, $2015 b$.

ZONTA, J. H. et al. Yield of cotton cultivars under different irrigation depths in Brazilian semi-arid region. Revista Brasileira de Engenharia Agrícola e Ambiental, 19: 748-754, 2015a. 